\title{
Okul öncesi öğretmenlerinin çocuk hakları ve çocuk katılım hakkına ilişkin görüşlerinin incelenmesi
}

\section{Investigation of pre-school education teachers' opinions concerning children's rights and children participation rights}

\author{
İshak Kozikoğlu ${ }^{1}$
}

Makale
Geçmişi
Geliş : 14 Mayıs 2019
Düzeltme : 11 Temmuz 2019
Kabul : 23 Temmuz 2019
Çevrimiçi : 24 Temmuz 2019

Makale Türü

Araştırma Makalesi
Article History

Received : 15 May 2019

Revised : 11 July 2019

Accepted : 23 July 2019

Online : 24 July 2019

\section{Article Type}

Research Article

\begin{abstract}
Öz: Bu araştırmanın amacı, okul öncesi öğretmenlerinin çocuk hakları ve çocuk katılım hakkına ilişkin görüşlerini belirlemektir. Durum çalışması olarak desenlenen bu araştırma, Van ilinde görev yapan 30 okul öncesi öğretmeniyle yürütülmüş̧ür. Araştırmada veri toplama aracı olarak, yarı-yapılandırılmış görüşme formu kullanılmıştır. Elde edilen veriler betimsel analiz tekniği kullanılarak çözümlenmiştir. Araştırmanın sonucunda, öğretmenlerin çocuk hakları denilince daha çok yaşamsal haklar, gelişme hakları, korunma hakları ve katılım haklarına vurgu yaptıkları belirlenmiştir. Öğretmenlerin çocuk katılım haklarına ilişkin en çok çocukların görüşlerini serbestçe ifade etmeleri ve kendileriyle ilgili karar alma süreçlerine katılma haklarını belirttikleri sonucuna ulaşılmıştır. Öğretmenlerin çocuk hakları ve çocuk katıllım hakları konusundaki uygulamalarının okul öncesi dönemde öğrenmenin doğasına uygun şekilde gerçekleştiği sonucuna ulaşılmıştır. Öğretmenlerin çocuklara haklarını öğretirken ve çocukların katılım hakkını sağlarken en çok ailelerin geleneksel tutumundan dolayı sorun yaşadıkları belirlenmiştir. Ayrıca, okul öncesi öğretmenlerinin çocukların bilişsel/gelişimsel özellikleri, kendilerini ifade etmede zorlanmaları veya çekingen davranmalarından kaynaklı sorun yașadıkları ortaya çıkmıștır.
\end{abstract}

Anahtar Kelimeler: Çocuk hakları; Çocuk katılım hakkı; Okul öncesi öğretmenleri; Erken çocukluk

Abstract: The aim of this study is to determine pre-school teachers' opinions concerning children's rights and children's participation rights. This case study was conducted with 30 pre-school teachers working in Van province. In this study, semi-structured interview form was used for data collection. The data were analyzed with descriptive analysis. As a result of this study, it was concluded that majority of teachers emphasize vital, development, protection and participation rights when they refer to children's rights. It was concluded that concerning children's participation rights teachers emphasized students' rights to freely express their views and participate in decision-making processes related to them. It was concluded that teachers' activities in pre-school period concerning children's rights and their participation rights are in accordance with the nature of the child's learning. It was determined that the most important problem that teachers face during teaching children the rights and providing children with participation rights is because of the traditional attitude of families. In addition, it was concluded that teachers face problems because of children's cognitive/developmental characteristics, having difficulty in expressing themselves or being shy because of parents' repressive attitude.

Keywords: Children rights; Children participation rights; Pre-school teachers; Early childhood

DOI: $\underline{10.24130 / \text { eccd-jecs. } 1967201932166}$

${ }^{1}$ Van Yüzüncü Yıl Üniversitesi, Eğitim Fakültesi, Eğitim Programları ve Öğretim Anabilim Dalı, ishakkozikoglu@yyu.edu.tr, ORCID: http://orcid.org/0000-0003-3772-4179 


\section{SUMMARY}

\section{Introduction}

Bringing up the individuals with cognitively, emotionally and psycho-socially healthy and conscious who are aware of their rights and obligations will be possible by providing supportive environments in which they can have positive experiences in the family, school and society. First of all, it is necessary for children to know their rights and freedoms to be able to express their opinions easily and to be able to decide on matters that concern them. This leads us to the concept of children's rights. It is important for the individuals in the society (family, school and environment) to know and apply children's rights in order to protect the rights of children in a healthy way.

The aim of this study is to determine pre-school teachers' opinions concerning children's rights and children participation rights. For this purpose, the following questions are addressed in this study:

1. What are children's rights and children's participation rights according to the opinions of the teachers?

2. What are pre-school teachers' activities that they are practicing concerning children's rights and children's participation rights?

3. What are the problems that pre-school teachers' have experienced concerning children's rights and children's participation rights?

4. What are the suggestions of pre-school teachers concerning children's rights and children's participation rights?

The researches revealed that pre-school period is an important process for cognitive, individual and socialemotional development of the child (Atay, 2009). It is thought that this study will contribute to the related literature in terms of determining preschool teachers' opinions on children's rights and children's participation rights, the activities they practice, the problems they face and their suggestions for solutions.

\section{Method}

This case study was conducted with 30 pre-school teachers working in the districts of İpekyolu, Tuşba and Edremit in Van province. In this study, the semi-structured interview form developed by the researcher was used for data collection. The data were analyzed with descriptive analysis.

In order to provide external reliability in this study, detailed explanations about the position of the researcher and the participants were presented, and in order to increase internal reliability, the data were coded separately by two different coders. In order to provide internal validity in this study, the integrity and consistency of the data were examined in detail, and in order to obtain external validity, detailed 
explanations were presented concerning the preparation of the interview form, data collection and analysis process.

\section{Results, Conclusion and Discussion}

In the interviews with teachers, it was concluded that teachers mostly emphasized vital rights, development rights, protection rights and participation rights when they refer to children's rights. It was concluded that concerning children's participation rights teachers emphasized students' rights to freely express their views and participate in decision-making processes that concern them. It was determined that the practices of pre-school teachers concerning children's rights and children participation rights are based on the activities such as play, drama, story, case study, etc. It was determined that the most important problem that teachers face during teaching children the rights and providing children with the right to participate is because of the traditional attitude of the families. In addition, it was concluded that teachers face problems because of children's cognitive/developmental characteristics, having difficulty in expressing themselves or being shy because of parents' repressive attitude.

Based on the results of this study, it was concluded that teachers' activities in the pre-school period concerning children's rights and their participation rights are in accordance with the nature of the child's learning. In addition, it can be said that pre-school teachers experienced problems in teaching children's rights due to families', children's and their own characteristics. Based on the results of this study and from the suggestions of the interviewed teachers, the following pedagogical implications were presented in this study:

1- Children's rights education programs can be prepared for preschool teachers to ensure child rights and child participation rights in preschool education institutions. Within the framework of these programs, trainings can be provided through web-based and distance education so that all teachers can participate in the trainings. In addition, more concrete learning can be realized by using visual and audio tools such as case studies, audio and videos.

2- Awareness of families on child rights and child participation rights can be provided.

3- School-family communication and cooperation can be supported in pre-school institutions. In this direction; families can participate in decision-making processes, share necessary information about their children, and social/cultural activities can be organized in and out of school for families.

4 - Elective courses on children's rights may be proposed to be added to teacher education programs.

5- This study is limited to pre-school teachers in Van and interview form as data collection tools. Similar studies can be carried out with teachers working in different regions, different education levels (primary, secondary, high school, etc.) and data collection tools such as survey, diary, observation can be used to examine teachers' practices concerning children's rights and children participation rights. 


\section{GİRİŞ}

Çocukların bilişsel, duyuşsal ve psiko-sosyal olarak sağlıklı, kendi hak ve yükümlülüklerinin farkında olan bilinçli bireyler olarak yetişebilmeleri, onların ailede, okulda ve toplumda olumlu yaşantılar geçirebilecekleri destekleyici ortamlar sağlanması ile mümkün olacaktır. Bunun gerçekleşebilmesi için her şeyden önce çocukların kendi hak ve özgürlüklerini bilmeleri, kendi düşüncelerini rahatça ifade edebilmeleri ve kendilerini ilgilendiren konularda karar verebilmeleri gerekmektedir. Bu da bizi çocuk hakları kavramına götürmektedir. Çocuk haklarının sağlıklı olarak korunabilmesi için toplumdaki bireylerin (aile, okul ve çevre) çocuk haklarını bilmesi ve uygulaması önem taşımaktadır.

\section{Çocuk Hakları}

Günümüz çağında, çocuğun sahip olduğu temel hak ve özgürlüklerin çocuğa tanıtılması, temel gerekliliklerden biri durumuna gelmiştir. Bu bağlamda, çocuk hakları kavramı ön plana çıkmaktadır. Çocuk hakları, çocuğun özgür bir birey olarak yetişmesinde ve içindeki yaşadığ1 topluma aktif katılım göstermesinde önemli bir rol oynamaktadır. Çocuk hakları, yasalara ve toplumsal normlara dayalı olarak, dünya üzerindeki çocuk olarak tanımlanan tüm bireylerin sahip olması gereken psikolojik, fiziksel, sosyal ve politik açıdan tüm hakları kapsayan evrensel bir kavram olarak nitelendirilebilir. Bu haklar, çocuğun kendini özgürce ifade edebilmesini, temel hak ve özgürlüklerini bilmesini ve kendini ilgilendiren durumlarda karar alma süreçlerinde aktif rol almasını amaçlamaktadır (Uçuş ve Şahin, 2012). Ayrıca, çocukların toplumda karar alma süreçlerine aktif katılımı, erken yaşlardan itibaren koruma altına alınmalı ve desteklenmelidir (Council of Europe, 2017).

Küçük yaştaki bireylerin hak kavramını algılayabilmesi güç olabilir, fakat yeterli destek sağlanarak onların çocuk haklarına ilişkin farkındalıkları artırılabilir, özellikle kendilerini ifade etme ve katılım sağlama becerileri geliştirilebilir (Casas ve diğerleri, 2006). Bu durumda, okul öncesi eğitiminden başlamak üzere okullara çocuk haklarının öğretilmesi bakımından önemli sorumluluklar düşmektedir. Çocuklara haklarının okul kurumlarında öğretilmesi, hem çocukların haklarını öğrenmesi hem de çocuk haklarının pedagojik katkısı bakımından önem taşımaktadır. $\mathrm{Bu}$ durumda okul öncesi eğitim kurumları, çocukları kendi haklarını öğrenecek ve başkalarının haklarını savunacak şekilde eğitmelidir (Lundy ve O'Lynn, 2018).

Çocuk hakları, çocukların fiziksel, bilişsel, duygusal, toplumsal ve ahlaki olarak özgür, bağımsız ve bilinçli bireyler olarak yetişebilmeleri için çocuklara tanınan hukuksal yetkilerdir (Akyüz, 2015; 
Karaman-Kepenekçi, 2010). Çocuk haklarının tanınması süreci çok uzun bir geçmişe sahiptir. Yıllarca çocukların hak sahibi olarak görülüp görülmemesi veya çocuk haklarından bahsetmenin onlara herhangi bir yarar sağlayıp sağlamayacağı tartışılmıştır. Bu tartışmaların sonucunda, genel olarak çocukları hak sahibi olarak görmenin hem kuramsal olarak hem de uygulamada fayda sağlayacağı kanısına varılmıştır (George, 2018). Bu doğrultuda, uluslararası çerçevede çocuk haklarının garanti altına alınması için çeşitli adımlar atılmıştır.

Çocuk hakları, tüm toplumların refah sisteminin bir parçası haline gelmiştir. Çocuk haklarının sağlanmasına yönelik ihtiyaçlar uluslararası düzeyde kabul edilmektedir (Akbar, Hameed, Khan ve Siddiqui, 2019). Çocuk haklarının yasal ve evrensel bir çerçevede tanımlanmasına ve tanınmasına yönelik hazırlanan en önemli belgelerden biri "Çocuk Hakları Sözleşmesi”dir. Çocuk Hakları Sözleşmesi, ilk olarak 1989 yılında Birleşmiş Milletler tarafından kabul edilmiş ve daha sonra Türkiye de dâhil olmak üzere dünya genelindeki neredeyse tüm ülkelerde yürürlüğe girmiştir. Bu sözleşme; resmi olarak çocuğa haklarını tanıtma, her çocuğun yaşam kalitesini standart bir düzeye getirme amacıyla oluşturulan ve çocukların evrensel anlamda hak ve özgürlüklerini içeren hukuki bir metin olma özelliği taşımaktadır. Sözleşmede yer alan çocuk hakları; yaşamsal haklar (çocuğun temel gereksinimlerinin karşılanmasına ilişkin haklar), gelişme hakları (çocuğun gelişimi için gerekli olan eğitim, oyun, dinlenme, din ve vicdan özgürlüğü gibi haklar), korunma haklar1 (çocuğun her türlü istismar, ihmal ve sömürüye karşı korunmasına ilişkin haklar) ve katılma hakları (çocuğun ailede, okulda ve toplumda etkin bir rol almasını sağlayan haklar) olmak üzere dört kategoride sınıflandırılabilir (Akyüz, 2015; Franklin, 1993). Bu yönüyle sözleşme, çocuk haklarına ilişkin durumları tek bir çatı altında birleştiren bir belge ve çocukların vatandaşlık vizyonunu belirleyen bir çerçeve olarak düşünülebilir (Roche, 1999). Çocuk hakları sözleşmesinde de vurgulandığı üzere, çocuk katılım hakkı çocuk haklarının önemli bir bileşeni olarak görülebilir. Çocuk katılımılla ilgili alanyazın (Percy-Smith ve Thomas, 2009; Landsdown, 2011), çocuk haklarının gerçekleştirilmesi için olanaklar ve katılımın niteliğinin önemli olduğunun altını çizmektedir. Ayrıca, alanyazında çocuk katılım hakkının diğer hakların gerçekleştirilmesi sürecini kolaylaştırdığı ifade edilmektedir (Perry-Hazan, 2019). Bu durum, çocuk hakları içerisinde çocuk katılım hakkının önemini ortaya koymaktadır.

\section{Çocuk Katılım Hakkı}

Çocuk katılım hakkı, demokrasi ve vatandaşlık kültürünün oluşturulabilmesi bakımından vazgeçilmez bir unsur olarak görülmektedir. Her ne kadar çocuk katılım hakkı yeni bir kavram olmasa da uygulanması halen bir güçlük olarak karşımıza çıkmaktadır (Correia, Camilo, Aguiar ve 
Amaro, 2019). Çocuk katılım hakk1, çocuğun görüş ve düşüncelerini rahatça ifade etmesini, bu görüşlerin önemsenmesini ve çocuğun kendisini ilgilendiren süreçlerdeki kararları almada aktif rol üstlenmesini içermektedir (Tüzün ve Sarışık, 2015). Bir başka deyişle, çocuk katılım hakkı çocuğun ailede, okulda ve toplumda kendisini etkileyebilecek her türlü karar alma süreçlerinde ve etkinliklerde etkin rol almasına ve kendi düşüncelerini özgürce ifade etmesine yönelik haklarını kapsamaktadır (Talay, Aslan ve Belkayalı, 2010). Nitekim Türkiye'nin de 20 yıldır tarafı olduğu Çocuk Hakları Sözleşmesi’nde çocuğun karar alma süreçlerine katılımı güvence altına alınmaktadır. Bu sözleşme kapsamındaki tüm hakların işe koşulmasında çocuğun katılım hakkının gözetilmesi öngörülmekte ve çocuk katılım hakk1, sözleşmenin temel ilkelerinden biri olarak ön plana çıkmaktadır (Tüzün ve Sarışık, 2015). Çocuk Hakları Sözleşmesi’nde çocuk katılım hakkına ilişkin 12. ve 13. maddeler; çocuğun kendisini ilgilendiren ve etkileyen durumlarda karar alma süreçlerine katılma ve görüş belirtme özgürlüğ̈ne sahip olduğunu vurgulamaktadır (Akyüz, 2015; Birleşmiş Milletler Çocuk Hakları Komitesi, 2009; Polat, Ersoy ve Toran, 2017).

Erken çocukluk eğitiminde başarının sağlanabilmesi ancak katılımcı bir pedagojiyle mümkün olabilmektedir. Çocukları ilgilendiren kararlarda onların düşünce ve görüşlerini paylaşması için alan ve zaman sağlamak hayati öneme sahiptir (Kennan, Brady ve Forkan, 2018; Sousa, Loizou ve Fochi, 2019). Bu durum, erken çocukluk eğitiminde çocuk katıllım hakkına işaret etmektedir. Çocuk katılımı üzerinde aile, okul ve toplum içinde birçok faktör etkilidir. Bu faktörler içinde aile önemli bir yere sahiptir, çünkü çocuk katılım hakkıyla ilgili ilk deneyimlerini, katılım becerilerini aile içinde yaşar ve geliştirir (Adhikari, 2016). Fakat çocuklar üzerindeki otorite ve kontrollerini kaybetme korkusu (Hart, 2016), çocuk haklarını dikkate almama veya önemsememeye (Franklin, 1993) neden olabileceğinden dolayı çocuk katılım hakkına bireylerin karşı çıkması veya direnç göstermesi görülebilmektedir.

Çocuk katılımı hem ülke çapında eğitim politikalarının belirlenmesinde hem de okul düzeyinde okuldaki etkinliklerin düzenlenmesinde, öğretme-öğrenme süreçlerinin planlanmasında, okul kurallarının oluşturulmasında çocukların görüş belirtme ve karar alma süreçlerinde katılımını gerektirmektedir. $\mathrm{Bu}$ durumda, çocuk katılımının eğitim süreçlerinin tümünde etkili olduğu söylenebilir (Birleşmiş Milletler Çocuk Hakları Komitesi, 2009). Eğitim süreçlerinde çocuk katıllım hakkının dikkate alınması, eğitim ortamlarını olumlu yönde etkilemektedir, çünkü ifade özgürlüğü ve karar alma süreçlerinde çocuk katılımının sağlandığı okullarda olumlu sonuçlar gözlemlenmektedir (Davies ve diğerleri, 2006). Alanyazında birçok çalışmada (Fudge Schormans ve Rooke, 2008; Hitzler ve Messmer, 2010; Pålsson, 2017), çocukların katılım süreçlerinde profesyonel eğiticinin kolaylaştırıcı veya zorlaştırıcı rolü ifade edilmektedir. Ayrıca, eğiticinin 
tutumu ve davranışları çocuğun karar alama süreçlerine katılımının sağlanmasında önemli bir role sahiptir (Ten Brummelaar ve diğerleri, 2018). Dolayısıyla, öğretmenler oyun ve diğer etkinliklerde çocukların karar alma ve katılım süreçlerini kolaylaştırarak çocuk merkezli bir yaklaşım benimsemelidir (Correia ve diğerleri, 2019).

Çocuğun gelişimi ve toplumsallaşması üzerinde en önemli belirleyici öncelikle aile, ikincisi ise okuldur. Aileden elde ettiği bilgi ve deneyimle okula başlayan çocuk, vaktinin önemli bir kısmını okulda akranlarıyla ve öğretmenleriyle geçirmektedir (Gözütok, 2007). Nitekim Bloom (1976) tarafından yürütülen araştırmada bir bireyin 18 yaşına kadar elde ettiği başarının yaklaşık olarak üçte biri (\%33) okul öncesi dönemdeki başarısıyla, yaklaşık olarak yarısı ise (\%42) ilköğretim dönemindeki başarısıyla açıklanabilmektedir. Dolayısıyla, bireyler arasında ileriki eğitim kademelerinde görülen başarı farklılıklarının önemli ölçüde okul öncesi ve ilköğretim dönemlerindeki eğitim yaşantılarıyla ilgili olduğu görülmektedir (Senemoğlu, 2001). Bu durumda, bireylerin hak ve özgürlüklerinin okul öncesi dönem gibi küçük yaşlardan itibaren çocuklara kazandırılması gerektiği ön plana çıkmaktadır ve okullara bu anlamda önemli sorumluluklar düşmektedir. Okullarda çocuk haklarının öğrenilmesi ve uygulanmasını sağlayacak en önemli aktörler öğretmenlerdir. Nitekim Çocuk Hakları Sözleşme'sinde çocuk hakları etkinliklerinin nitelikli ve başarılı olabilmesinin öğretmenlerin çocuk hakları konusundaki yeterliğine ve uyguladıkları öğretme-öğrenme süreçlerinin etkililiğine bağlı olduğu vurgulanmaktadır (Uçuş ve Şahin, 2012). Bu durumda, çocuk hakları ve çocuk katılım hakkına ilişkin çocukların haklarını bilmesi, bilinçlendirilmesi ve uygulamalı etkinliklerle çocukların hak ve özgürlüklerini benimseyerek daha bilinçli bireyler olarak yetişebilmelerinde okul öncesi öğretmenlerinin önemli bir rol üstlendiği söylenebilir. Dolayısıyla, okul öncesi öğretmenlerinin çocuk hakları ve çocuk katılım hakkına ilişkin görüşleri ve uygulamalarının belirlenmesine ihtiyaç duyulduğu görülmektedir.

\section{Araştırmanın Amacı ve Önemi}

Bu araştırmanın amacı, okul öncesi öğretmenlerinin çocuk hakları ve çocuk katılım hakkına ilişkin görüşlerini belirlemektir. Bu amaç doğrultusunda araştırmada aşağıdaki sorulara yanıt aranmıştır:

1. Okul öncesi öğretmenlerinin görüşlerine göre;

a. çocuk hakları,

b. çocuk katılım hakları nelerdir?

2. Okul öncesi öğretmenlerinin çocuk hakları ve çocuk katılım haklarına ilişkin uyguladıkları etkinlikler nelerdir? 
3. Okul öncesi öğretmenlerinin çocuk hakları ve çocuk katılım haklarına ilişkin uygulamalarda yaşadıkları sorunlar nelerdir?

4. Okul öncesi öğretmenlerinin çocuk hakları ve çocuk katılım haklarına ilişkin önerileri nelerdir?

Yurtdışı alanyazında çocuk hakları ve çocuk katılım hakkına ilişkin görüşleri, uygulamaları inceleyen ve bunun önemini ortaya koyan çeşitli çalışmalara (Akbar, Hameed, Khan ve Siddiqui, 2019; Asimaki, Koustourakis, Lagiou ve Berdeni, 2018; Eriksen, 2018; Eriksen ve Debalkie, 2019; Freeman, 2018; Kutsar ve diğerleri, 2019; Quennerstedt, 2011; Sheridan ve Samuelsson, 2001) ulaşılmıstır. Yurtiçi alanyazında çocuk hakları ve çocuk katılım hakkına ilişkin çalışmalar incelendiğinde ise ebeveynlerin çocuk haklarına ilişkin görüşlerini (Akgül, 2015; Dinç, 2015; Kızılırmak, 2015; Yurtsever, 2009), ilköğretim öğrencilerinin çocuk haklarına ilişkin algılarını (Ersoy, 2011), ilköğretim Türkçe öğrenci ders kitaplarında çocuğun katılım hakları konusuna ne düzeyde yer verildiğini (Nayır ve Karaman Kepenekçi, 2011), sınıf öğretmenlerinin çocuk haklarına ilişkin tutumlarını (Peker, 2012), sosyal bilgiler öğretmen adaylarının çocuk haklarına yönelik farkındalıklarını (Hançer, 2019), öğretmen adaylarının çocuk haklarına ilişkin görüşlerini/tutumlarını (Faiz ve Kamer, 2017; Kaya, 2011; Leblebici ve Çeliköz, 2015), çocuk hakları sözleşmesine yönelik öğretmenlerin ve okul yöneticilerinin görüşlerini (Uçuş ve Şahin, 2012) ve Türkiye'deki okullarda çocuk katılımını (Tüzün ve Sarışık, 2015) inceleyen çalşmaların olduğu görülmektedir. Bununla birlikte bu araştırma konusuna paralel olarak, okul öncesi öğretmenlerinin çocuk haklarına ve çocuk katılım hakkına ilişkin görüşlerini veya tutumlarını (Banko, 2017; Kor, 2013; Koran ve Avc1, 2017), okul öncesi öğretmen adaylarının çocuk haklarının öğretimi amacıyla geliştirdikleri uygulamalara ilişkin görüşlerini (Neslitürk ve Ersoy, 2007) inceleyen çalışmalar da mevcuttur. Alanyazındaki çalışmalar incelendiğinde okul öncesi eğitiminde çocuk hakları ve çocuk katılım hakkını inceleyen çalışmaların sınırlı sayıda olduğu ve bu çalışmalarda sadece okul öncesi öğretmen/öğretmen adaylarının tutumları veya görüşlerinin incelendiği görülmektedir. Yapılan araştırmalar okul öncesi dönemin çocuğun bilişsel, bireysel ve sosyal-duygusal gelissimi için önemli bir süreç olduğunu ortaya koymuştur (Arslanargun ve Tapan, 2012; Atay, 2009; Barnett, 2008; Osborn ve Milbank, 1987; Vural, 2006). Dolayisiyla bu çalışmanın okul öncesi öğretmenlerinin çocuk hakları ve çocuk katılım hakkına ilişkin görüşleri, uyguladıkları etkinlikler, yaşadıkları sorunlar ve çözüm önerilerini belirlemesi açısından alanyazındaki çalışmalardan farklılaştı̆̆1 ve kapsam yönüyle ilgili alanyazına katkı sunacağ1 düşünülmektedir. 


\section{YÖNTEM}

\section{Araştırmanın Modeli}

$\mathrm{Bu}$ araştırmada, nitel araştırma desenlerinden durum çalışması kullanılmıştır. Durum çalışmalarında bir veya birkaç olay ve kişiler derinlemesine incelenmekte ve incelenen durumu etkileyen veya durumdan etkilenen faktörler üzerine odaklanılmaktadır (Cohen, Manion ve Morrison, 2005; Yıldırım ve Şimşek, 2013). Bu araştırmada, üzerinde çalışılan durum okul öncesi eğitim döneminde "çocuk hakları ve çocuk katılım hakkı" olarak belirlenmiş ve araştırma bu duruma ilişkin öğretmenlerin görüşleri, uyguladıkları etkinlikler ve yaşadıkları sorunlar çerçevesinde derinlemesine ele alınmıştır. Bu nedenle bu araştırmanın durum çalışması olarak nitelendirilmesi uygun görülmüştür.

\section{Çalışma Grubu}

Araştırmanın çalışma grubunu, Van ilinde bulunan bağımsız anaokullarında ve anasınıflarında görev yapmakta olan 30 okul öncesi öğretmeni oluşturmaktadır. Araştırmada öğretmenler uygun örnekleme yöntemi (convenience sampling) kullanılarak belirlenmiştir. Uygun örnekleme yönteminde araştırmacı, ulaşılabilirlik ve kolay erişim durumuna göre ihtiyaç duyduğu örnekleme ulaşmaya çalışmaktadır (Büyüköztürk ve diğerleri, 2016). Bu araştırmada, görüşme yapılacak öğretmenler belirlenirken ulaşılabilirlik ve araştırmaya katılmada gönüllülük esası dikkate alınmıştır. Dolayısıyla zaman, emek ve olanaklar çerçevesinde 30 okul öncesi öğretmeni çalışma grubuna dahil edilmiştir. Görüşme yapılan öğretmenlerin 18’i kadın, 12’si erkektir. Öğretmenlerin 12'si il merkezinde, 10’u ilçe merkezinde, 8'i ise köyde görev yapmaktadır. Ayrıca, öğretmenlerin 13'ü 1-5 yıl arası, 9’u 6-10 yıl arası, 9’u ise 11 yll ve üzeri mesleki deneyime sahiptir.

\section{Veri Toplama Araçları ve Verilerin Toplanması}

$\mathrm{Bu}$ araştırmada, okul öncesi öğretmenlerinin çocuk hakları ve çocuk katılım haklarına ilişkin görüşlerini belirlemek amacıyla yarı-yapılandırılmış görüşme formu kullanılmıştır. Araştırmacı tarafından oluşturulan görüşme formu, sekiz sorudan oluşmaktadır. Görüşme formu hazırlanırken; öğretmenlerin çocuk ve çocuk katılım haklarına ilişkin bilgileri, çocuklara haklarını bilme ve uygulama konusunda okulda ne tür etkinlikler gerçekleştirdikleri, çocuklara haklarını öğretirken yaşadıkları temel sorunlar ve neler yapılması gerektiğine ilişkin önerilerine ilişkin açık uçlu ve kolay anlaşılabilir sorulara yer verilmiştir. Görüşme formundaki soruların anlaşllırllğını ve araştırmanın amacına uygun olup olmadığını belirlemek amacıyla Okul Öncesi Eğitimi, Eğitim 
Programları ve Öğretim, Ölçme-Değerlendirme ve dil uzmanı olmak üzere dört uzmandan görüş alınmıştır. Uzmanların görüş ve önerileri doğrultusunda soru ifadelerinde dil ve anlatım bakımından gerekli düzeltmeler yapılmıştır. Taslak görüşme formunun ön uygulaması olarak üç öğretmenle görüşme yapılarak görüşme formundaki soruların öğretmenler tarafindan anlaşılırlığ1 ve formun araştırmanın amacına hizmet edip etmediği test edilmiştir. Böylece, görüşme formuna son hali verilmiştir.

Araştırma verileri, araştırmacı tarafından belirlenen okullardaki okul öncesi öğretmenleriyle yüz yüze görüşmelerin yapılması yoluyla toplanmıştır. Görüşmeler öğretmenlerle belirlenen gün ve saatlerde uygun bir ortamda yüz yüze gerçekleştirilmiş ve öğretmenlerin de izni alınarak ses kayıt cihazıyla kayıt altına alınmıştır. Veri toplama süreci 15 gün ve her bir öğretmenle yapılan görüşme ise yaklaş1k olarak 40 dakika sürmüştür.

\section{Verilerin Analizi}

Araştırmada, öğretmenlerle yapılan görüşmelerden elde edilen verilerin analizinde betimsel analiz tekniği kullanılmıştır. Betimsel analizde betimsel analiz için tematik çerçeve oluşturma, belirlenen temalara göre verileri kodlama, bulguları tanımlama ve yorumlama gibi aşamalar izlenmektedir (Yıldırım ve Şimşek, 2013). Bu araştırmada veri analizi sürecinde belirtilen aşamalar izlenmiştir. Öncelikle araştırmada analiz için tematik çerçeve oluşturulmuş ve temalar altında uygun kodlar belirlenmiştir. Temalar oluşturulurken araştırmadan elde edilen bulgular ve önceden hazırlanmış ölçütler (çocuk hakları, çocuk katılım hakkı, çocuk ve çocuk katılım hakk1 öğretimi, yaşanılan sorunlar ve çözüm önerileri) temel alınmıştır. Bu ölçütler görüşme formundaki sorularla örtüşmektedir. Daha sonra bulgulara ilişkin ayrıntılı betimlemelere yer verilmiş ve araştırma verileri öğretmen görüşlerinden doğrudan alıntılarla zenginleştirilmiştir. Öğretmen görüşlerinin doğrudan alıntılarla sunulmasında "Ö1, Ö2, Ö3" şeklinde kısaltma yapılımıştır. Son olarak temalara göre düzenlenen veriler yorumlanmıştır.

Araştırmada dış güvenirliği sağlamak için araştırmaya katılan öğretmenlere ilişkin ayrıntılı açıklamalara yer verilmiş, iç güvenirliği sağlamaya yönelik ise biri araştırmacı olmak üzere iki ayrı kodlayıcı tarafindan veriler ayrı ayrı kodlanmıştır. Kodlayıcılar arası uyum yüzdesini hesaplamak için Miles ve Huberman (1994) tarafindan önerilen güvenirlik formülü (Güvenirlik=Görrüs

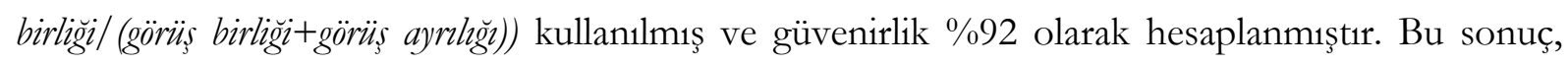
yapılan kodlamaların güvenilirliğinin yeterli düzeyde olduğunu göstermektedir (Miles ve Huberman, 1994). Araştırmada iç geçerliği artırmak için veriler sürekli olarak gözden geçirilmiş, dış geçerliği artırmak için ise araştırma süreçlerine ilişkin ayrıntılı açıklamalara yer verilmiştir. 


\section{BULGULAR}

Okul öncesi öğretmenleriyle yapılan görüssmeler sonucunda; katılımc1 görüşleri "Çocuk hakları" "Çocuk katılım hakları”, "Çocuk hakları ve çocuk katılım hakkına ilişkin uygulamalar”, "Çocuk hakları ve çocuk katılım hakkına ilişkin uygulamalarda yaşanılan sorunlar" ve "Çocuk hakları ve çocuk katılım hakkına ilişkin öneriler” olmak üzere beş tema alında gruplandırılmıştır. Belirlenen temalara ilişkin öğretmen görüşleri ve betimlemeler aşă̆ıda sunulmuştur.

\section{Çocuk Hakları}

Bu temaya ilişkin öğretmenlere "Çocuk hakları deyince aklınıza ne geliyor? Sizce çocukların ne tür hakları vardır?” soruları yöneltilmiştir. Görüşme yapılan öğretmenler çocuk haklarını en çok sırasıyla eğitim, yaşama, sağlık, barınma, oyun oynama, ihmal ve istismardan korunma, ifade özgürlüğü hakları olarak ifade etmişlerdir. Bu duruma ilişkin görüş belirten öğretmen görüşlerinden ön plana çıkanlara aşağıda yer verilmiştir.

"Çocuk hakları deyince her çocuğun eğitim ve yaşama hakkı, ihmal ve istismardan korunma hakk1, düşünce ve ifade özgürlüğü gibi hakları olduğu geliyor aklıma" (Ö1).

"Çocuğun oyun, barınma, eğitim, sağlık, fiziksel ve duygusal ihtiyaçlarının karşılanması gibi hakları vardir" (Ö3).

Yukarıda öğretmen görüşlerinde de belirtildiği üzere öğretmenler, çocuk hakları denilince daha çok "Çocuk Hakları Sözleşmesinde" de yer alan yaşamsal haklar, gelişme hakları, korunma hakları ve katılım haklanına vurgu yaptıklanı görülmektedir. Bu hakların yanı sıra, bazı öğretmenler çocuk haklarına ilişkin çocukların beslenme, katılım, sevgi/ilgi gibi duygusal ve psikolojik ihtiyaçlar, güvenlik, din ve vicdan özgürlüğü haklarının olduğuna vurgu yapmışlardır. Bu duruma ilişkin görüş belirten öğretmen görüşlerinden birine aşağıda yer verilmiştir.

"Çocuk hakları denince aklıma ilk gelen onların güvenliğini sağlama, psikolojik hakları, korunma ve barınma hakları geliyor" (Ö13).

Öğretmenler çocukların bütün haklarını belirtmişlerdir. Bu durum öğretmenlerin çocuk hakları konusunda bilgili oldukları şeklinde yorumlanabilir. 


\section{Çocuk Katılım Hakları}

Bu temaya ilişkin öğretmenlere "Çocuk katılım hakkı deyince aklınıza ne geliyor? Sizce çocukların ne tür katılım hakları vardır?” soruları yöneltilmiştir. Görüşme yapılan öğretmenlerin çocuk katılım haklarına ilişkin en çok sırasıyla çocukların görüşlerini serbestçe ifade etmeleri ve kendileriyle ilgili karar alma süreçlerine katılma haklarını belirttikleri görülmektedir. Bu duruma ilişkin görüş belirten öğretmen görüşlerinden ön plana çıkanlara aşağıda yer verilmiştir.

\footnotetext{
"Çocukların da bir insan olarak duygu ve düşüncelere sahip olduğu, bu duygu ve düşüncelerini söyleyebilme hakkı geliyor aklıma. Bence çocuklar oyun sırasında, evde, okulda söz hakkını kullanabilmeli ve söz hakkı verilmelidir" (Ö4).

"Çocuk katılım hakkı denince çocukların kendileri ile ilgili verilen kararlarda fikir belirtebilme ve karar alabilme hakkı geliyor aklıma" (Ö18).
}

Ayrıca, bazı öğretmenler çocuk katılım haklarına ilişkin çocukların görüşüne danışılma, eşit imkânlardan yararlanma, din ve vicdan özgürlüğü, etkinliklere kendi isteği ile katılma haklarından bahsetmişlerdir. Bu duruma ilişkin görüş belirten öğretmen görüşlerinden bazılarına aşağıda yer verilmiştir.

\footnotetext{
"Düşüncelerini özgürce ve çekinmeden söyleyebilme hakkı, eşit imkânlardan yararlanma hakkı geliyor aklıma" (Ö7).

"Çocuğun birey olabilmesi ve topluma kazandırılması açısından kazandığı sosyal bilinç. Görüşlerini ifade etme özgürlüğü, düşünce, din ve vicdan özgürlüğü diyebilirim." (Ö9).
}

Öğretmenler çocukların katılım haklarını ifade özgürlüğü ve karar alma süreçlerine katılma olarak belirtmişlerdir. Bu durum öğretmenlerin çocuk katılım haklarından haberdar oldukları şeklinde değerlendirilebilir.

\section{Çocuk Hakları ve Çocuk Katılım Hakkına İlişkin Yapılan Uygulamalar}

Bu temaya ilişkin öğretmenlere "Çocuklara haklarını bilme ve uygulama konusunda okulda ne tür etkinlikler yapıyorsunuz?” ve "Çocukların katılım hakkını sağlamaya yönelik okulda neler yapıyorsunuz, ne tür etkinlikler gerçekleştiriyorsunuz?” soruları yöneltilmiştir. Görüşme yapılan öğretmenler çocuklara haklarını bilme ve uygulama konusunda okulda en çok sırasıyla rol model olduklarını, çocukların fikirlerini dinlediklerini ve dikkate aldıklarını, oyun/sıraya girme/drama/hikâye/örnek olay gibi etkinlikler aracıllğıyla çocukların haklarını öğrenmelerini 
sağladıklarını ifade etmişlerdir. Bu duruma ilişkin görüş belirten öğretmen görüşlerinden çarpıcı olanlar aşağıda sunulmuştur.

\footnotetext{
"Sınıf içerisinde yaşanan olaylar ve durumlarda çocukların kendilerinin farkında olmaları, kendi haklarını savunmaları ve aynı zamanda arkadaşlarının haklarını da çiğnememeleri konusunda model olurum ve çocuklara da bunun bilincini yaşatııım" (Ö5).

"Çocuklara sahip oldukları hakları hikâyelerle, oyunlarla, drama etkinlikleriyle anlatıyorum. Sınıf içerisinde uygulayacağımız etkinlikleri seçerken öncelikle onların fikirlerini dinliyorum. Etkinliklerde çocukları daha özgür bırakarak ve yaratıclıklarını destekleyerek onlara rehberlik ediyorum" (Ö25).
}

Ayrıca, bazı öğretmenler çocuklara haklarını bilme ve uygulama konusunda yardımcı olmak için çocukları kendi kararlarını vermek için teşvik etme, çocuk hakları panosu oluşturma, programda esneklik yapma, seçim oylaması yapma, pankart oluşturma, farkındalık yaratma gibi etkinlikler yaptıklarını belirtmişlerdir. Bu duruma ilişkin görüss belirten öğretmen görüşlerinden bazıları aşağıda sunulmuştur.

"Her zaman çocuklara "böyle yapabilirsin, istersen böyle kullanabilirsin" gibi önerilerde bulunarak kendi kararını vermesine teşvik ediyorum" (Ö23).

"Okulumda 20 Kasım Çocuk Hakları gününde farkındalık yaratmaya yönelik etkinlikler yaptırırım ve koridorlarımızda "Çocuk Hakları" panosu oluştururum" (Ö21).

Görüşme yapılan öğretmenler çocukların katılım hakkını sağlamaya yönelik okulda en çok sırasıyla onlara söz hakkı vererek fikirlerini söylemelerini sağlama, sınıf kurallarını beraber oluşturma, kendi etkinliklerini oluşturmalarını sağlama ve seçim hakkı tanıma (okul meclisi, seçmeli dersler, etkinlikler) gibi uygulamalar yaptıklarını ifade etmişlerdir. Bu duruma ilişkin görüş belirten öğretmen görüşlerinden ön plana çıkanlara aşağıda yer verilmiştir.

"Öncelikle sınıf kurallarını çocuklarla birlikte oluşturuyorum. Ayrıca, çocuğun sınıfta yapılacak olan değişikliklerde söz hakkına sahip olmasını, fikirleri doğrultusunda değişiklik yapılmasını destekliyorum" (Ö14).

"Okulumuzda okul meclislerinin seçimi, seçmeli derslerden istenilen derslerin seçilmesi, sportif ve kültürel etkinliklerden istediklerini seçmeleri katılım hakkının kullanılmasına yönelik faaliyetlerimizdendir" (Ö21).

Yukarıda öğretmen görüşlerinde de belirtildiği üzere öğretmenlerin çoğunun, çocukların katıllım hakkını sağlamaya yönelik okulda öğrencilere söz ve seçme hakkı tanıyacak etkinliklere yer verdikleri görülmektedir. Bunun yanı sıra, öğretmenlerin bazıları çocukların katılım hakkını 
sağlamaya yönelik okulda çocukları aktif kılma, karar alma süreçlerine dâhil etme, oyun/drama/sanat etkinlikleri yapma, yaratıcılıklarını geliştirme, aileleri bilgilendirme, fırsat eşitliği sunma, onları dinleme gibi uygulamalar yaptıklarını vurgulamışlardır. Bu duruma ilişkin görüş belirten öğretmen görüşlerinden bazıları aşağıda sunulmuştur.

"Çocukların dâhil olabileceği bütün kararları ortak alamaya çalışıyorum. Etkinliklerde çocukların sosyal-duygusal gelişim alanlarına hitap edecek etkinlikler yapmaya, kendilerini ifade edebilmeleri için drama, sanat gibi etkinliklere yer vermeye çalışıyorum" (Ö18).

"Etkinliklerde mümkün olabildiğince çocukları aktif kılmaya çalışıyorum. Aynı zamanda etkinliklere katılmak istemeyen çocukları dinleyerek böyle bir hakları oluğunu belirtiyorum" (Ö28).

Öğretmenlerin çocuk hakları ve çocuk katılım hakları konusunda farklı etkinlikler gerçekleştirdikleri ve bu konuda çaba harcadıkları söylenebilir.

\section{Çocuk Hakları ve Çocuk Katılım Hakkına İlişkin Uygulamalarda Yaşanılan Sorunlar}

Bu temaya ilişkin öğretmenlere “Çocuklara haklarını öğretirken yaşadığınız sorunlar nelerdir?” ve “Çocukların katılım hakkını sağlamada yaşadığınız sorunlar nelerdir?” soruları yöneltilmiştir. Görüşme yapılan öğretmenler çocuklara haklarını öğretirken ve çocukların katılım hakkını sağlarken yaşadıkları en temel sorunu ailenin geleneksel tutumu olarak ifade etmisslerdir. $\mathrm{Bu}$ duruma ilişkin görüş belirten öğretmen görüşlerinden çarpıcı olanlar aşağıda sunulmuştur.

"Bu konudaki en büyük sorun ailelerin tutumu. Çoğu ailede gördüğüm kadarıyla çocuklarının düşüncelerine önem verilmiyor. Çocuklar öyle yetiştiği için de bizim kazandırmaya çalıştıklarımız çocuğun öğrendikleriyle çelişiyor ve oturmuyor" (Ö30).

"Bu konuda çocukların okul dişında rol model aldığı kişilerin yanlış davranışları bizi zorluyor. Ama annem de böyle, amcam da böyle tepkileriyle sık sık karşılaşıoruz" (Ö2).

"En temel sorun ailelerin çocuklarının ayrı bir birey olduklarını; onların ebeveyni olmak, onlara sahip olmak ve her durumda onlara adına karar vermek demek olmadığını anlatmakta zorlanmamız" (Ö23).

Yukarıda öğretmen görüşlerinde de belirtildiği üzere öğretmenlerin çoğu, çocuklara haklarını öğretmede ve çocukların katılım hakkını sağlamada ailenin bu konuda çocuğu desteklememeleri, onlar adına karar almaları, bilinçli olmamaları, çocuğu birey olarak görmemeleri, çocukların rol model aldıkları kişilerin yanlış davranışları şeklinde aileden kaynaklı sorunlar yaşadıklarını vurgulamışlardır. Bunun yanı sıra birçok öğretmen, çocuklara haklarını öğretmede ve çocukların katılım hakkını sağlamada çocukların haklarını kavrayamaması, çocukların çekingen 
davranmasından kaynaklı sorunlar yaşadıklarını belirtmişlerdir. Bu duruma ilişkin görüş belirten öğretmen görüşlerinden bazıları aşağıda sunulmuştur.

"Çocuklara haklarını söylediğimizde bu haklar onlara çok soyut gelebilmekte ve hatta hak kelimesini
çok iyi anlamlandıramamaktalar. Dolayısılla bunları somutlaştırarak anlatmakta zorlanıyorum" (Ö17).
"Çocuklar evde hep susturulup konuşma, sus gibi baskılara maruz kaldıkları için çocuklar okulda çok
çekingen davranıyorlar, kendilerini ifade edemiyorlar. Anne-baba tutumları çocukları pasifleştiriyor" (Ö22).

Yukarıda öğretmen görüşlerinde de belirtildiği üzere, çocuklar soyut düşünemedikleri için birçok öğretmenin çocuklara haklarını somutlaştırarak anlatmada zorlandığı görülmektedir. Öğretmenler çocuklara haklarını öğretme ve çocukların katılım hakkını sağlamaya yönelik özellikle ailenin olumsuz tutumundan dolayı çocukların kendini ifade etmede zorlandıkları veya utandıkları için sorun yaşadıklarını vurgulamışlardır. Ayrıca, bazı öğretmenler toplumun bakış açısı, çocuğun benmerkezci davranması nedenlerinden dolayı çocuklara haklarını öğretmede ve çocukların katılım hakkını sağlamada sorun yaşadıklarını belirtmişlerdir. Bu duruma ilişkin görüş belirten öğretmen görüşlerinden bazıları aşağıda sunulmuştur.

\footnotetext{
"Çocuğun toplumda gördügüu, yetiştiği zihniyeti değiştirmek zor oluyor. Çocuğa yetiştiği toplumda değer verilmediği, fikirleri önemsenmediği ve kendi kararlarını verme şansı tanınmadığı için ikilemde kalıyor" (Ö28).
}
"Çocuklar benmerkezci oldukları bu dönemlerde kendi hakları dışında başkalarının haklarının olduğu ve bunlara sayg1 göstermek zorunda olmaları onlar için zor oluyor" (Ö29).
"Çocukların yaşlarından dolayı bencillik davranışları çok oluyor. Hep kendi isteklerinin gerçekleşmesini bekliyorlar. Bu da hakları öğretmede sorun oluşturuyor" (Ö15).

Yukarıda öğretmen görüşlerinde de belirtildiği üzere bazı öğretmenler çocuklara haklarını öğretmede ve çocukların katılım hakkını sağlamada toplumdaki olumsuz bakış açısından kaynaklı çocuklara toplumda karar verme hakkının tanınmaması ve çocuğun gelişim döneminden dolayı empati kuramaması, bencil davranması gibi durumlardan dolayı sorun yaşadıklarını ifade etmişlerdir.

$\mathrm{Bu}$ durumda, öğretmenlerin çocuklara haklarını öğretmede ve çocukların katılım hakkını sağlamada gerek aile ve çevreden gerekse öğrenci özelliklerinden kaynaklı sorunlar yaşadıkları söylenebilir. 


\section{Çocuk Hakları ve Çocuk Katılım Hakkına İlişkin Öneriler}

Bu temaya ilişkin öğretmenlere "Çocukların haklarını daha iyi öğrenebilmeleri için önerileriniz nelerdir? Sizce neler yapılmalıdır?" ve "Okul öncesi kurumlarda çocukların katılımlarını veya katılım hakkını sağlamak için önerileriniz nelerdir? Sizce neler yapılmalıdır?” soruları yöneltilmiştir. Görüşme yapılan öğretmenler çocukların haklarını daha iyi öğrenebilmeleri, okul öncesi kurumlarda çocukların katılımlarını veya katılım hakkını sağlamak için çeşitli önerilerde bulunmuşlardır. Bu önerilerden en çok tekrarlananlar sırasıyla ailelerin bilinçlendirilmesi, oyun/drama/örnek olay/hikâye vb. etkinliklerle hakların somutlaştırılarak kavratılması, toplumdaki tüm bireylerin çocuk hakları konusunda eğitilmesi, çocuğa kendini ifade etmesi için firsatlar sunulması, çocuğun karar verebilecekleri seçenekler/tercihler sunulması, öğretmenlere hizmet-içi eğitimlerin verilmesi, çocuk haklarıyla ilgili görseller hazırlanmasıdır. Bu duruma ilişkin öğretmen önerilerinden ön plana çıkanlar aşağıda sunulmuştur.

"Öncelikle öğretmenler bu konuda anlayışlı ve duyarlı olmalı, öğretmenlere hizmet-içi eğitimler verilmelidir" (Ö20).

"Tüm çocukların oyun, drama vb. çeşitli etkinliklerle aktif katılımı sağlanmalıdır. Sınıfta söz hakkı her çocuğa verilerek kendilerini ifade etmelerine firsat verilmelidir" (Ö19).

"Aileler çocukların hakları ve en önemli haklarından biri olan katılım hakları konusunda bilgilendirilmeli, onlara yönelik seminerlerle veya bizzat konuşularak aileler bilinçlendirilmelidir" (Ö16).

"Çocukların kararları, fikirleri önemsenmeli. Öğretmen çocuklara alternatif sunmalı ve öğrenciye seçme hakk1 vermeli" (Ö1).

Ayrıca, bazı öğretmenler çocuk hakları öğretimi ve çocuk katılım hakkını sağlamaya yönelik öğrencilerin fikirlerini önemseyerek ve dikkate alarak onların değerli olduğunu hissettirme, çocuğun kısıtlanmaması, kamu spotlarının hazırlanması, yetişkinlerin model olması, okul-aile iletişimi ve işbirliğinin desteklenmesi gibi önerilerde bulunmuşlardır. Bu duruma ilişkin öğretmen önerilerinden bazıları aşağıda sunulmuştur.

"Öncelikle okul-aile işbirliği bu konuda çok önemlidir. Eğitimcilerin bu konuda okul-aile iletişim ve işbirliğini desteklemesi lazım" (Ö11).

"Çocuğun değerli olduğu çocuğa hissettirilmeli. Çocuk haklarına ilişkin her türlü görsel ve işitsel uyarıcıların kullanılarak kamu spotları hazırlanmalıdır" (Ö6). 
$\mathrm{Bu}$ durumda, öğretmenlerin okul öncesi kurumlarda çocukların katılımlarını veya katılım hakkını sağlamak için tüm vatandaşlara, ailelere ve öğretmenlere önemli sorumluluklar düştüğünü ve bunun için okul içi ve okul dışında katılımcı etkinliklere yer verilmesi gerektiğini düşündükleri yorumlanabilir.

\section{SONUÇ ve TARTIŞMA}

Öğretmenlerle yapılan görüşmelerde öğretmenlerin çocuk hakları denilince daha çok yaşamsal haklar, gelişme hakları, korunma hakları ve katılım haklarına vurgu yaptıkları belirlenmiştir. Ayrıca, öğretmenlerin çocuk katılım haklarına ilişkin en çok sırasıyla çocukların görüşlerini serbestçe ifade etmeleri ve kendileriyle ilgili karar alma süreçlerine katılma haklarını belirttikleri sonucuna ulaşılmıştır. Kor'un (2013) okul öncesi öğretmenleriyle yaptığ1 çalışmada, öğretmenlerin çoğunun çocuğun yaşama, gelişme ve katılım hakk1, çocuğun görüşlerinin önemsenmesi gibi hakları hakkında bilgi sahibi oldukları ve öğretmenlerin öğretme-öğrenme sürecinde çocukların haklarını gözettikleri belirlenmiştir. Benzer şekilde; Banko (2007), Filiz ve Kamer (2017), Peker (2012), Kızılırmak (2015), Leblebici ve Çeliköz'ün (2015) çalışmalarında, ebeveyn, öğretmen veya öğretmen adaylarının çocuk haklarına ilişkin genel olarak yüksek düzeyde olumlu tutuma sahip oldukları ve olumlu görüş bildirdikleri sonucuna ulaşılmıştır. Akbar, Hameed, Khan ve Siddiqui'nin (2019) yaptıkları çalışmada, okul yöneticilerinin çocuk haklarına yönelik yüksek duyarlılı̆ga sahip oldukları belirlenmiştir. Hançer’in (2019) yaptığı çalışmada, öğretmen adaylarının çocuk hakları konusunda yeterli düzeyde bilgi sahibi oldukları sonucuna ulaşılmıştır. Akgül'ün (2015) çalışmasında, ebeveynlerin çocuk haklarının önemli olduğunu ifade ettikleri ve sırasıyla yaşama, eğitim, gelişim ve korunma hakkına vurgu yaptıkları belirlenmiştir. Yurtdışı alanyazında da, okul öncesi dönemdeki öğretme-öğrenme süreçlerinde çocuk katılım hakkının önemine vurgu yapan çalışmalar mevcuttur (Eriksen, 2018; Sheridan ve Samuelsson, 2001). Bu araştırmadan farklı olarak, Uçuş ve Şahin'in (2012) yaptıkları çalışmada, sınıf öğretmenlerinin büyük çoğunluğu ve okul yöneticilerinin çocuk haklarını yeterince bilmedikleri belirlenmiştir. Ayrıca, bu çalışmada çocukların en önemli hakkı olarak yaşama hakkının belirtildiği, katılım hakkına ise önemli haklar arasında yer verilmediği saptanmıştır. Benzer şekilde, Dinç’in (2015) çalışmasında, ebeveynlerin çocuk haklarını yeterince bilmedikleri ve bilinçlendirmeye ihtiyaç duydukları saptanmıştır. Tüzün ve Sarışık'ın (2015) Türkiye'de okullarda çocuk katılımına yönelik hazırladıkları raporda, çocukların kendilerini ilgilendiren durumlarda ve öğretme-öğrenme süreçlerinde karar alma süreçlerinde aktif rol üstlenebileceklerine dikkat çekmişler, fakat Türkiye'deki mevcut uygulamaların öğretme-öğrenme süreçlerinde çocuk katılımının çok sınırlı olduğunu gösterdiğini belirtmişlerdir. Ayrıca, okullarda karar alma süreçlerinde çocuk katılımının sınırlı olmasının 
öğretmen ve okul yöneticilerinin donanım ve tutumlarıyla yakın ilişkili olduğunu ifade etmişlerdir. Bu durumda, alanyazındaki araştırmalarda okul öncesi öğretmenlerinin çocuk katılım halklarına ilişkin görüsslerinin farklılaştığı söylenebilir. Bu araştırma sonuçlarından hareketle, öğretmenlerin çocuk hakları ve çocuk katılım haklarından haberdar oldukları, bu hakları doğru algıladıkları söylenebilir. Bu sonuç, çocuk hakları eğitiminde en önemli aktörlerden biri olan öğretmenlerin çocuk ve çocuk katılım haklarına ilişkin bilgi sahibi olmaları açısından olumlu bir durum olarak değerlendirilebilir. Çocukların sınıfta düşüncelerini özgürce ifade etmeleri onların tüm demokratik süreçlere katılımını artıracaktır (Paddison, Docherty ve Goodlad, 2008). Kutsar ve diğerlerinin (2019) sekiz Avrupa ülkesinde sekiz yaşındaki 8000 çocukla yürüttüğü çalışmalarında, çocuk katılımı ve adil davranılmanın nitelikli bir yaşamın en önemli belirleyicileri olduğu belirlenmiştir. Bu bağlamda, çocuklarla çalışan profesyonel eğitimcilerin öğrenme ortamında çocuk katılımını sağlayabilmeleri elzem bir öneme sahiptir (Polat, Ersoy ve Toran, 2017). Dolayisıyla, okul öncesi öğretmenlerinin çocuk hakları, çocuk katılım haklarından haberdar olmaları ve bu hakları doğru alg1lamaları küçük yaşlardan itibaren okullarda demokrasi kültürünün oluşturulması, çocuklara demokrasi bilincinin kazandırılması ve çocukların katılım hakları açısından olumlu bir sonuç olarak düşünülebilir.

Çocuklara haklarını bilme ve uygulama konusunda, öğretmenlerin rol model olma, çocukların fikirlerini dinleme ve dikkate alma, oyun/sıraya girme/drama/hikâye/örnek olay gibi somut etkinlikler aracıllğıyla çocukların haklarını öğrenmelerini sağladıkları belirlenmiştir. Çocukların katılım hakkını sağlamaya yönelik ise öğretmenlerin çocuklara söz hakkı vererek fikirlerini söylemelerini sağlama, sınıf kurallarını beraber oluşturma, kendi etkinliklerini oluşturmalarını sağlama ve seçim hakkı tanıma (okul meclisi, seçmeli dersler, etkinlikler) uygulamalarını gerçekleştirdikleri belirlenmiştir. Bunun yanı sıra, öğretmenlerin bazılarının çocukların katılım hakkını sağlamaya yönelik okulda çocukları aktif kıldıkları, karar alma süreçlerine dâhil ettikleri, onları dinledikleri, oyun/drama/sanat etkinlikleri yaptıklanı, yaratıcılıklarını geliştirdikleri, aileleri bilgilendirdikleri, fırsat eşitliği sundukları belirlenmiştir. Bu araştırma sonuçlarına paralel olarak, Neslitürk ve Ersoy'un (2007) okul öncesi öğretmen adaylarıyla yaptıkları çalışmada, öğretmen adaylarının çocuk hakları eğitiminde genellikle drama, anadili ve oyun gibi etkinliklerinden yararlandıkları belirlenmiştir. Dinç'in (2015) ebeveynlerle yaptığ çalışmada, ebeveynlerin çocuk hakları eğitimine ilişkin model olma, evde yaparak yaşayarak öğrenme, örnek vererek anlatma gibi uygulamalar gerçekleştirdikleri belirlenmiştir. Uçuş ve Şahin (2012) çalışmalarında, çocuk haklarının okullarda uygulanmasına ilişkin öğretmenlerin doğrudan uygulamalarının olmadığı, fakat öğretmenlerin sınıf içinde ve okulda öğrencilere karşı saygılı tutum geliştirdikleri, katılım haklarına dikkat ettikleri sonucuna ulaşmışlardır. Bu araştırmadan farklı olarak, Banko'nun (2017) 
çalışmasında, okul öncesi öğretmenlerinin çocuk haklarına yönelik uygulamalarının istenilen düzeyde olmadığı, öğretmenlerin etkinlikler hakkında çocukların görüşlerini dikkate almadıkları belirlenmiştir. Benzer şekilde, Asimaki, Koustourakis, Lagiou ve Berdeni'nin (2018) çalışmalarında, öğretmenlerin işe koştukları pedagojik uygulamalarla çocukların dinlenme, boş zaman, oyun oynama ile ifade ve katılım haklarını önemli ölçüde kısıtladıkları belirlenmiştir. Çocuk hakları eğitimiyle ilgili en önemli hususlardan biri hakların öğretimindeki yöntemleri belirleme ve belirlenen yöntemlerin etkili kullanılmasıdır (Uçuş ve Şahin, 2012). Nitekim son yıllarda, farklı disiplin alanlarındaki araştırmacılar, çocuk hakları ile ilgili çalışmalarda farklı disiplin, kuram ve yöntemlerin sentezini vurgulamaktadır (Moody ve Darbellay, 2019). Bu bağlamda, öğrenci meclisleri öğrencilerin okullarda karar alma süreçlerine dâhil edilmesinde en önemli araçlardan biridir (Tüzün ve Sarışık, 2015). Benzer şekilde, insan haklarının öğretiminde oyun, drama ve hikâye gibi etkinliklerin genelde kullanıldığı ifade edilmektedir (Darling, 2004). Bu durumda, bu araştırma sonuçlarından hareketle öğretmenlerin çocuklara haklarını bilme, uygulama konusunda ve çocukların katılım hakkını sağlamaya yönelik daha çok somut etkinlikler gerçekleştirdikleri, çocuklara rol model oldukları, onların görüşlerini dikkate aldıkları ve onları karar alma süreçlerine dâhil ettikleri görülmektedir. Uluslararası alanda yapılan çalışma sonuçları okullarda çocuk haklarının öğrenilmesi ve uygulanmasının önemini ortaya koymaktadır (Covell, 2010; Lo, Leung ve Yuen, 2015). Nitekim okul öncesi dönemde çocukların katılım haklarını sağlamaya yönelik çocukları karar alma süreçlerine katma, çocukların görüşlerini dikkate alma ve destekleme, onlara davranışlarıyla örnek/model olma gibi uygulamaların gerçekleştirilmesi gerektiği vurgulanmaktadır (Hill ve diğerleri, 2004). Bu araştırmada, okul öncesi öğretmenlerinin çocuklara haklarını bilme ve uygulama konusunda rol model olmaları, çocukların fikirlerini dikkate almaları, farklı yöntem ve teknikler aracıllğı̆la somut etkinlikler gerçekleştirmeleri çocuk haklarının öğretimi ve uygulanması açısından olumludur. Dolayısıyla, öğretmenlerin çocuk hakları ve çocuk katılım hakları konusundaki uygulamalarının okul öncesi dönemde öğrenmenin doğasına uygun şekilde gerçekleştiği söylenebilir.

Öğretmenlerin çocuklara çocuk haklarını öğretirken ve çocukların katılım hakkını sağlarken en çok ailenin bu konuda çocuğu desteklememeleri, çocuğun fikrini almamaları, onun adına karar almaları, bilinçli olmamaları, çocuğu birey olarak görmemeleri, çocukların rol model aldıkları kişilerin yanlış davranışları gibi ailenin geleneksel tutumundan kaynaklı sorunlar yaşadıkları sonucuna ulaşılmıştır. Bu araştırma sonuçlarına paralel olarak, Eriksen ve Debalkie (2019) çalışmalarında, çocuk haklarının öğretiminde en önemli engellerden birinin ailenin geleneksel çocuk yetiştirme tarzı olduğunu ortaya çıkarmışlardır. Benzer şekilde, Uçuş ve Şahin'in (2012) çalışmalarında, öğretmenler çocuk hakları öğretiminde aile eğitiminin çok önemli olduğuna dikkat 
çekmişler ve aile bilinçli olmadığı sürece çocuk haklarıyla ilgili yapılan etkinliklerin verimli olmayacağını savunmuşlardır. Dinç (2015) çalışmasında, ebeveynlerin çocuk hakları konusunu yeterince bilmedikleri ve bilinçlendirme gereksinimi duydukları sonucuna varmıştır. Filiz ve Kamer'in (2017) çalışmalarında, öğretmen adayları ailelerin çocuk haklarını yeterince önemsemediklerini ve dolayısıyla çocuklarının görüşlerini dikkate almaları gerektiğini belirtmişlerdir. Quennerstedt'in (2011) 1997- 2008 yılları arasında yayımlanan 35 çalışmayı incelediği araştırmasında, çocuk hakları ve katılım hakkının sağlanabilmesi için ailelerin çocuk hakları konusunda bilinçlendirilmesi gerektiği ortaya çıkmıştır. Bu durumda, öğretmenlerin çocuklara haklarını öğretirken ve çocukların katılım hakkını sağlarken en çok ailelerin geleneksel tutumundan dolayı sorun yaşadıkları ve bu yüzden ailelerin çocuk ve çocuk katılım hakları konusunda bilinçlendirilme ihtiyacı olduğu söylenebilir. Bunun yanı sıra, bu araştırmada öğretmenlerin çocuklar soyut düşünemedikleri için çocuklara haklarını somutlaştırarak anlatmada zorlandıkları, ailenin olumsuz tutumundan dolayı çocukların kendini ifade etmede zorlandıkları veya utandıkları için öğretmenlerin sorun yaşadıkları, toplumun bakış açısı, çocuğun gelişim döneminden dolayı benmerkezci davranması gibi nedenlerden dolayı öğretmenlerin çocuklara haklarını öğretmede ve çocukların katılım hakkını sağlamada sorun yaşadıkları belirlenmiştir. Dolayısıyla, çocukların bilişsel ve gelişimsel döneminden dolayı soyut düşünememeleri, benmerkezci davranmaları, ailenin baskıc1 tutumundan dolayı kendilerini ifade etmede zorlanmaları veya çekingen davranmalarından kaynaklı öğretmenlerin çocuklara haklarını öğretirken ve çocukların katılım hakkını sağlarken sorun yaşadıkları söylenebilir. Fakat alanyazında her ne kadar erken çocukluk dönemindeki çocuklara haklarını öğretmek zor olsa da gerekli destek sağlanarak çocukların çocuk haklarına ilişkin farkındalık ve katılımlarının artırılabileceği ifade edilmektedir (Casas ve diğerleri, 2006). Wang ve diğerleri (2018) çalışmalarında, öğretmen-çocuk etkileşiminin çocuğun görüşlerini özgürce ifade etme ve katılımını etkilediğini ortaya koymuşlardır. Bu durumda, çocuklara haklarını öğretme ve çocukların katılım hakkını sağlamada öğretmenlere olumlu ve katılımcı bir sınıf iklimi oluşturma, öğrenci özelliklerini tanıma, uygun yöntemler ve etkinlikler uygulama gibi önemli sorumluluklar düştüğünü söylemek mümkündür.

Araştırmada, görüşme yapılan öğretmenlerin araştırmanın bulgularında da belirtildiği üzere çocukların haklarını daha iyi öğrenebilmeleri, okul öncesi eğitim kurumlarında çocukların katılımlarını veya katılım hakkını sağlamak için topluma, ailelere, öğretmenlere, çocuklara, öğretme-öğrenme ortamlarına yönelik çeşitli önerilerde bulunmuşlardır. Dolayısıyla araştırma sonuçlarından ve görüşme yapılan öğretmenlerin önerilerinden hareketle araştırmada aşağıdaki önerilere yer verilmiştir: 
1- Okul öncesi eğitim kurumlarında çocuk hakları ve çocuk katılım haklarını sağlamaya ilişkin okul öncesi öğretmenlerine yönelik çocuk hakları eğitimi programları hazırlanabilir. Bu programlar çerçevesinde eğitimler, web tabanlı ve uzaktan eğitim yoluyla verilerek tüm öğretmenlerin eğitimlere katılmaları sağlanabilir. Ayrıca eğitimlerde örnek olay, ses, video gibi görsel ve işitsel araç-gereçlerden faydalanılarak daha somut öğrenmeler gerçekleştirilebilir.

2- Çocuk hakları ve çocuk katılım haklarına ilişkin ailelerin bilinçlendirilmesi sağlanabilir. Bu doğrultuda; ailelerin çocuklarıyla çocuk haklarını nasıl konuşacakları, çocuklarına haklarını nasıl benimsetebilecekleri, çocuklarının günlük yaşamda ve eğitimde haklarını nasıl gözetebilecekleri konularında drama, simülasyon, tartışma gibi yöntemlerden yararlanılarak çocuk hakları ve çocuk katılım haklarına yönelik aile eğitimleri düzenlenebilir.

3- Okul öncesi eğitim kurumlarında okul-aile iletişimi ve işbirliğinin desteklenmesi sağlanabilir. Bu doğrultuda; ailelerin karar alma süreçlerine katılmaları, çocukları hakkında gerekli bilgi paylaşımında bulunmaları, aileler için okul içi ve okul dışı sosyal/kültürel etkinliklerin düzenlenmesi sağlanabilir.

4- Öğretmen eğitimi programlarına çocuk haklarına ilişkin seçmeli veya zorunlu dersler eklenmesi önerilebilir.

5- Bu araştırma Van ilinde görev yapan okul öncesi öğretmenleri ve veri toplama aracı olarak görüşme formuyla sınırlıdır. İleriki çalışmalarda farklı bölgelerde, farklı eğitim kademelerinde (ilkokul, ortaokul, lise vb.) görev yapan öğretmenlerle benzer çalışmalar yapılabilir ve anket, günlük tutma, gözlem vb. veri toplama araçları kullanılarak öğretmenlerin çocuk hakları ve çocuk katılım hakkına ilişkin uygulamaları incelenebilir.

\section{KAYNAKÇA}

Adhikari, H. (2016). Children's participation decision making process in the family affairs of female commercial sex workers (FCSWS) and its' impact. Journal of Alternative Perspectives in the Social Sciences, 8(1), 99-111.

Akbar, S., Hameed, A., Khan, M. M., \& Siddiqui, K. (2019). Sensitivity level of educational administrators towards child rights. Review of Economics and Development Studies, 5(1), 67-78.

Akgül, M. S.. (2015). İlkokul ögrenci velilerinin çocuk baklarna ilişkin görïslerinin değerlendirilmesi (Yayınlanmamıs yülkesek lisans tęi). Tokat: Gaziosmanpaşa Üniversitesi.

Akyüz, E. (2015). Ulusal ve uluslararası bukukta çocuk haklarnnn ve güvenlï̈inin korunması. Ankara: Milli Eğitim Basım Evi. 
Arslanargun, E. ve Tapan, F. (2012). Okul öncesi eğitim ve çocuklar üzerindeki etkileri. Abant İzzet Baysal Üniversitesi Ë̈itim Fakültesi Dergisi, 11(2), 219-238.

Asimaki, A., Koustourakis, G. S., Lagiou, A., \& Berdeni, N. (2018). A sociological approach to the rights of children in Greek primary education. Multidisciplinary Journal of Educational Research, 8(3), 309-337.

Atay, M. (2009). Okullarda eğitimin amacı, yöntemi ve içeriği. In Tüzün, I. (Ed.), Eğitim bakker ve eğitimde haklar: Uluslararası insan haklar belgeleri uşı̆ğnda ulusal mev₹uatın değerlendirilmesi (pp. 101-148). İstanbul: Yelken Basim.

Banko, Ç. (2017). Okul öncesi ögrretmenlerinin çocuk baklarna ilişkin tutum, davranış ve görüslerinin incelenmesi (Yaymlanmamıs yülksek. lisans teri). Ankara: Hacettepe Üniversitesi.

Barnett, W. S. (2008). Preschool education and its lasting effects: Research and policy implications. National Institute for Early Education Research Rutgers, The State University of New Jersey.

Birleşmiş Milletler Çocuk Hakları Komitesi. (2009). Birleşmis milletler çocuk haklar komitesinin çocuk haklarna dair sö̊leşmeye ilişkin genel yorumlar 2008-2011. Ankara: Uluslararası Çocuk Merkezi ICC Çocuk Hakları Serisi 10.

Büyüköztürk, Ş., Çakmak, E. K., Akgün Ö. E., Karadeniz, Ş. ve Demirel, F. (2016). Bilimsel arastırma yöntemleri (21. baski). Ankara: Pegem Akademi Yayıncilık.

Casas, F., Saporiti, A., González, M., Figuer, C., Rostan, C., Sadurní, M., .. Rago, M. (2006).Children's rights from the point of view of children, their parents and their teachers: A comparative study between Catalonia (Spain) and Il Molise (Italy). The International Journal of Children's Rights, 14, 1- 75.

Cohen, L., Manion, L. ve Morrison, K. (2005). Research methods in education. (5th Ed.). London: Routledge Falmer.

Correia, N., Camilo, C., Aguiar, C., \& Amaro, F. (2019). Children's right to participate in early childhood education settings: A systematic review. Children and Youth Services Review, 100, 76-88.

Council of Europe (2017). Young people's access to rights. Recommendation CM/Rec(2016)7 and explanatory memorandum. Retrieved from https://rm.coe.int/1680702b6e.

Covell, K. (2010). School engagement and rights-respecting schools. Cambridge Journal of Education, 40(1), 39-51.

Darling, L. F. (2004). Teaching human rights in elementary classrooms: A literary approach. Canadian Social Studies, 39(1).

Davies, L., Williams, C., Yamashita, H., \& Ko Man-Hing, A. (2006). Inspiring schools impact and outcomes: Taking up the challenge of pupil participation. Carnegie Young People Initiative \& Esmee Fairbairn Foundation. 
Dinç, B. (2015). Okulöncesi eğitim kurumuna devam eden çocukların ebeveynlerinin çocuk hakları eğitimi konusundaki görüşleri. Eğitimde Nitel Araștrrmalar Dergisi, 3(1), 7-25. DOI:10.14689/issn.2148-2624.1.3c1s1m

Eriksen, E. (2018). Democratic participation in early childhood education and care-serving the best interests of the child. Nordic Early Childhood Education Research Journal, 17(10), 1-15.

Eriksen, E. A. B., \& Debalkie, D. K. (2019). Challenges facing the implementation of children's rights in primary schools in Ethiopia. Journal of the European Teacher Education Network, 14, 116-126.

Ersoy, A. F. (2011). Elementary school students' perceptions related to children's rights. Elementary Education Online, 10(1), 20-39.

Faiz, M. ve Kamer, S. T. (2017). Prospective teachers' opinions concerning children's rights. Journal of Education and Learning, 6(3), 118-128.

Franklin, B. (1993). Çocuk haklar. İstanbul: Ayrıntı Yayıncılık.

Freeman, M. (Ed.). (2018). Children's rights: New issues, new themes, new perspectives. BRILL.

Fudge Schormans, A., \& Rooke, J. (2008). When there are no choices: The consequences of a lack of adult living placements for young adults with intellectual and/or developmental disabilities leaving child welfare care. Journal of Developmental Disabilities, 14(1), 107-126.

George, R. (2018) Rewriting children's rights judgments: From academic vision to new practice, Journal of Social Welfare and Family Law, 40(1), 126-128.

Gözütok, D. (2007). Öğretim ilke ve yöntemleri. Ankara: Ekinoks Yayınc1lık.

Hançer, G. (2019). Çocuk haklarn ve çocuk istismar konusunda sosyal bilgiler ögretmen adaylarnm görüsleri (Yayımlanmamıs yülesek lisans teri). Kastamonu: Kastamonu Üniversitesi.

Hart, R. A. (2016). Cocuklarn katılım: Kuram ve uygulamada toplum gelisimi ve çevre korumasinda gens yurttaşlar içermek. Ankara: Nobel Yayıncilik.

Hill, M., Davis, J., Prout, A. \& Tisdall, K. (2004). Moving the participation agenda forward. Children \& Society, 18(2), 77-96. DOI: 10.1002/CHI.819

Hitzler, S., \& Messmer, H. (2010). Group decision making in child welfare and the pursuit of participation. Qualitative Social Work, 9(2), 205-226.

Karaman-Kepenekçi, Y. (2000). İnsan baklar eğitimi. Ankara: Anı Yayınc1lı.

Kaya, S. Ö. (2011). Öğretmen adaylarmın çocuk haklar ile ilgili görüsleri (Yayımlanmamıs yülesek lisans teri). Afyon: Afyon Kocatepe Üniversitesi.

Kennan, D., Brady, B., \& Forkan, C. (2018). Supporting children's participation in decision making: A systematic literature review exploring the effectiveness of participatory processes. The British Journal of Social Work, 48(7), 1985-2002. 
Kor, K. (2013). Okul öncesi ögretmenlerinin çocuk baklarna konusundaki görüslerinin incelenmesi (Yayımlanmamıs yü̈ksek lisans teجৃi). Çanakkale: Çanakkale On Sekiz Mart Üniversitesi.

Koran, N. ve Avc1, N. (2017). Perceptions of prospective pre-school teachers regarding children's right to participate in classroom activities. Educational Sciences: Theory and Practice, 17(3), 10351059 .

Kuz1lırmak, K. (2015). Ankara il merkęinde yaşayan 61-72 aylar arasinda çocuğu olan annelerin çocuk baklar ve anne olmaya ilişkin bilgi düreyleri arasindaki iliskinin incelenmesi (Yaymlanmamıs yüksek lisans teri). Ankara: Gazi Üniversitesi.

Kutsar, D., Soo, K., Strózik, T., Strózik, D., Grigoraș, B., \& Bălțătescu, S. (2019). Does the realisation of children's rights determine good life in 8-year-olds' perspectives? A comparison of eight European countries. Child Indicators Research, 12(1), 161-183.

Lansdown, G. (2011). A framework for monitoring and evaluating children's participation a preparatory draft for piloting. London: Save the Children.

Leblebici, H. ve Çeliköz, N. (2015). Öğretmen adaylarının çocuk haklarına yönelik tutumlar1. International Journal of Social Sciences and Education Research, 3(1), 307-318. DOI: $10.24289 /$ ijsser.270584.

Lo, Y., Leung, Y., \& Yuen, W. (2015). Exploring school ethos: an investigation of children's human rights in two secondary institutions in Hong Kong. Intercultural Education, 26(3), $192-$ 209.

Lundy, L., \& O’Lynn, P. (2018). The education rights of children. International Human Rights of Children, 1-19.

Miles, M. B., \& Huberman, A. M. (1994). Qualitative Data Analysis (2nd edition). Thousand Oaks, CA: Sage Publications.

Moody, Z., \& Darbellay, F. (2019). Studying childhood, children, and their rights: The challenge of interdisciplinarity. Childhood, 26(1), 8-21.

Nayir, F. ve Karaman Kepenekçi, Y. (2011). Children's participation rights in elementary schools' Turkish textbooks. Elementary Education Online, 10(1), 160-168.

Neslitürk, S. ve Ersoy, F. (2007). Okulöncesi öğretmen adaylarının çocuk haklarının öğretimine yönelik görüşleri. Ë̆itimde Kuram ve Uygulama. 3(2), 245-257.

Paddison, R., Docherty, I. W., \& Goodlad, R. (2008). Responsible participation andhousing: Restoring democratic theory to the scene. Housing Studies, 23(1), 129-147. DOI: 10.1080/02673030701731274

Pålsson, D. (2017). Conditioned agency? The role of children in the audit of S wedish residential care. Child \& Family Social Work, 22, 33-42.

Perry-Hazan, L. (2019). Conceptualising conflicts between student participation and other rights and interests. Discourse: Studies in the Cultural Politics of Education, 1-16. 
Peker, R. (2012). Sinf ögretmenlerinin demokratik tutumlar ile çocuk baklarna yönelik tutumlarmmn değerlendirilmesi-Manisa ili örneği (Yaymlanmamıs yülksek lisans teri). Hatay: Mehmet Akif Ersoy Üniversitesi.

Percy-Smith, B., \& Thomas, N. (Eds) (2009). A handbook of children and young people's participation: perspectives from theory and practice. London: Routledge.

Polat, B. D., Ersoy, Ö. A. ve Toran, M. (2017). Çocuk katılımı farkındalık ölçeği (ÇKFÖ): Ölçek geliştirme, güvenirlik ve geçerlik çalışması. Erken Çocukluk Çalışmalar Dergisi, 1(2), 186-215.

Roche, J. (1999). Children: Rights, participation and citizenship. Childhood, 6(4), 475-493.

Osborn, A. F., \& Milbank, J. E. (1987). The effects of early education: A report from the Child Health and Education Study. Oxford University Press, USA.

Quennerstedt, A. (2011). The construction of children's rights in education- A research synthesis. The International Journal of Children's Rights, 19(18), 661-678. DOI: $10.1163 / 157181811 X 570708$

Senemoğlu, N. (2001). Çocuk hakları, çalışan çocuklar ve eğitim sorunları. Milli Eğitim Dergisi, 151, $25-35$.

Sheridan, S., \& Samuelsson, I. P. (2001). Children's conceptions of participation and influence in pre-school: A perspective on pedagogical quality. Contemporary Issues in Early Childhood, 2(2), 169-194.

Sousa, J., Loizou, E., \& Fochi, P. (2019). Participatory pedagogies: Instituting children's rights in day to day pedagogic development. European Early Childhood Education Research Journal, 27(3), 299-304.

Talay, İ., Aslan, F. ve Belkayalı, N. (2010). Okul öncesi eğitim kurumlarında doğa dostu ve çocuk katılımı temelli dış mekan tasarım yaklaşımları bir proje önerisi. Kastamonu Eğitim Dergisi, 18(1), 317-322.

Ten Brummelaar, M. D., Harder, A. T., Kalverboer, M. E., Post, W. J., \& Knorth, E. J. (2018). Participation of youth in decision-making procedures during residential care: A narrative review. Child \& Family Social Work, 23(1), 33-44.

Tüzün, I. ve Sarısık, Y. (2015). Türkiye'de okullarda çocuk katılım: Durum analiə⿱亠乂 İstanbul: İstanbul Bilgi Üniversitesi Yayınları.

Uçuş, Ş. ve Şahin, A. E. (2012). Çocuk haklar1 sözleşmesine yönelik öğretmenlerin ve okul yöneticilerinin görüssleri. Adnan Menderes Üniversitesi Ë̆itim Bilimleri Dergisi, 3(1), 25-41.

Vural, E. D. (2006). Okul öncesi eğitim programindaki duyussal ve sosyal becerilere yönelik hedeflere uygun olarak hazurlanan aile katıliml sosyal beceri eğitimi programmmn cocuklarda sosyal becerilerin gelissimine etkisi (Yaymlanmamıs yü̈ksek lisans tęi). İzmir: Dokuz Eylül Üniversitesi.

Wang, C., Harrison, L. J., McLeod, S., Walker, S., \& Spilt, J. L. (2018). Can teacher-child relationships support human rights to freedom of opinion and expression, education and participation?. International Journal of Speech-Language Pathology, 20(1), 133-141. 
Yıldırım, A. ve Şimşek, H. (2013). Sosyal bilimlerde nitel araştırma yöntemleri. Ankara: Seçkin Yayincilik.

Yurtsever, M. (2009). Ebeveyn çocuk haklar tutum ölçeğinin gelistirilmesi ve anne babalarn cocuk haklarna yönelik tutumlarmm frakel değģskenler açısından incelenmesi (Yayınlanmamıs doktora tezi). İstanbul: Marmara Üniversitesi. 